\title{
A insustentável leveza do estado: devastação, genocídio, doenças e miséria nas fronteiras contemporâneas da Amazônia, no Maranhão
}

\author{
István van Deursen VARGA ${ }^{1}$
}

\begin{abstract}
RESUMO
Foram discutidas as trajetórias das frentes de expansão e seus impactos ambientais, sociais e étnicos na região denominada Amazônia maranhense. As informaçōes utilizadas resultam de pesquisa bibliográfico-documental e de campo, em que foram colhidos depoimentos de trabalhadores rurais e índios, habitantes da região. Foi demonstrado que, mesmo entre as comunidades Guajajara da Terra Indígena Araribóia (na qual se concentra esta pesquisa), opçōes distintas de convívio com a sociedade envolvente e com suas frentes de expansão vêm sendo tomadas, acarretando distintos impactos em sua qualidade de vida; também foi demonstrado que as comunidades indígenas mais vulneráveis a estas frentes de expansão são as Awa, as quais se encontram em iminente risco de extinção. Em conclusão, algumas considerações: sobre as medidas a serem tomadas, no âmbito das políticas públicas, diante da rápida devastação atualmente em andamento na região, e da gravidade das condiçôes de vida de seus habitantes; sobre a importância do Maranhão no campo dos estudos sobre as formas de sociabilidade, dominação, violência e resistência no campo, como contraponto às que caracterizaram o chamado "ciclo do cangaço".
\end{abstract}

PaLaVRAS-CHAVE: Amazônia maranhense, Devastação, Trabalhadores rurais, Comunidades indígenas.

\section{The unbearable lightness of State: devastation, genocide, illnesses and misery in the contemporary frontiers of Amazon, in Maranhão}

\begin{abstract}
We discussed the trajectories of the capitalism expansion frontiers, and it environmental, social and ethnic impacts, on the Maranhão Amazon. The cited information result from bibliographic, documental and field research, in which we collected testimonies of rural workers and Indians, living in the region. We demonstrated that, even among Terra Indígena Araribóia’s Guajajara communities (in which we concentrated this research), distinct options of conviviality with the surrounding society and its expansion frontiers are being made, carrying distinct impacts at their quality of life; we also demonstrated that the Indian communities most vulnerable to this expansion frontier are the Awa ones, which remain in imminent extinction risk. We conclude with some considerations: about the measures to be taken in the public policies field of action, facing the currently very quick devastation of the region, and the severe life conditions of its inhabitants; about the importance of Maranhão in the study field about peasant's sociability, domination, violence and resistance forms, as a counterpart to those which characterized the so called "cangaço" cycle in Northeastern Brazil.
\end{abstract}

KEYWORDS: Maranhão Amazon, Devastation, Rural workers, Indian communities.

\footnotetext{
1 Praça Madre Deus, 2; $2^{0}$ andar; bairro Madre Deus; São Luís/MA; CEP 65.025-560; tels.: (98) 3232-3837, 8803-1115. e-mail: ivarga@uol.com.br
} 


\section{INTRODUÇÃOO}

\section{MEIO-NORTE, PRÉ-AMAZÔNIA, AMAZÔNIA MARANHENSE}

Foram apresentadas e discutidas, neste trabalho, as trajetórias das frentes de expansão e seus impactos ambientais, sociais e étnicos que incidiram e incidem na região denominada Amazônia maranhense (ou, como preferem alguns, "Pré-Amazônia").

Atentos e conectados aos trabalhos dos autores que, a partir da década de 1970, tomam o Maranhão e o Pará como referência empírica (cf. Figueiredo, 2000), também foi adotado, aqui, o conceito "frente de expansão", por sua operacionalidade para a discussão do impacto dos empreendimentos de capital sobre as relaçóes entre índios e trabalhadores rurais - os segmentos sociais mais vulneráveis e submetidos às piores condições de vida na região.

O estado do Maranhão, localizado na fronteira entre o nordeste e a Amazônia brasileiros, apresenta características de ambas as regiōes: embora do ponto de vista geográfico e político-administrativo seja considerado nordestino, partes da porção centro-sul (onde predomina o ecossistema de cerrado) e oeste (onde predomina o da floresta tropical) de seu território estão, desde 1969, incorporadas à chamada "Amazônia Legal" , uma vez que apresentam muitas identidades com os estados amazônicos: pluviosidade, hidrografia, relevo, vegetação, fauna, a história de sua ocupação humana, e as características culturais, sociais e econômicas de seus habitantes.

Independentemente, portanto, da real posição de suas atuais fronteiras ecológicas, no constante recuo imposto pela devastação, a delimitação econômica e social da Amazônia maranhense abarca, além do oeste, todo o centro-sul do estado, onde se verifica um panorama ecológico, econômico e social que testemunha os resultados da interação de dois cenários, típicos e complementares, das políticas fundiárias praticadas no país: a tradição dos latifúndios monocultores e da pecuária extensiva do nordeste, e a modernidade do assalto predatório à Amazônia, em escala industrial, por grandes empresas do Sul e do Sudeste.

Nos mapas fisiográficos dos anos 1970, a Amazônia maranhense ocupava uma extensa área entre as bacias dos rios Gurupi, a oeste, e Mearim, a leste.

A presença da floresta tropical densa (equatorial), com árvores altas e grande ocorrência de palmáceas, que caracterizaria o ecossistema típico da Pré-Amazônia em sua porção maranhense, só se verifica, atualmente, no polígono definido, grosso modo, entre os rios Zutiwa (a sudeste), Gurupi (a oeste) e Buriticupu (ao sudoeste) e pela linha seca que delimita a fronteira noroeste da Terra Indígena (TI) Alto Turiaçu.

1 e assim fazendo jus, a partir do governo Sarney, tanto a recursos da Superintendência de Desenvolvimento do Nordeste (SUDENE) como da Superintendência de Desenvolvimento da Amazônia (SUDAM).
A região da TI Araribóia e do Projeto de Colonização Agrícola de Buriticupu ${ }^{2}$, que se constitui exatamente no entorno da TI Araribóia, delimitam a região em que se concentrou a quase totalidade de nosso trabalho de campo: localizam-se em plena Amazônia maranhense; segundo os critérios de regionalização do Instituto Brasileiro de Geografia e Estatística, pertencem à Mesorregião do Oeste Maranhense, microrregião do Pindarés.

Em seu conjunto, o relevo da região do Projeto de Colonização Agrícola de Buriticupu e da TI Araribóia é parte das últimas ramificaçôes setentrionais do planalto maranhense, apresentando algumas elevaçôes, que se constituem em prolongamentos da serra do Gurupi.

A cidade de Buriticupu, formada em torno do núcleo inicial do Projeto de Colonização, localiza-se sobre um grande tabuleiro, de cerca de 200 metros de altitude, separado por vales no sentido norte-sul, onde o solo predominante é o latossolo amarelo, argiloso, profundo, com baixas reservas de nutrientes minerais, dito "distrófico", pobre, pouco produtivo (Silva, 1975) e sujeito a erosōes.

A rede hidrográfica da região está ligada à bacia do Mearim, mais especificamente à sub-bacia do rio Pindaré, no médio vale.

O clima nessa região é quente, com dias ensolarados o ano inteiro, não se manifestando, portanto, as estaçōes inverno, outono e primavera. Ocorrem, basicamente, dois períodos: o chuvoso, de dezembro a junho (época que corresponderia ao verão e ao outono) e o de estiagem, de julho a novembro (que corresponderia ao inverno e à primavera). Ao período chuvoso o povo da região chama de inverno, e ao de estiagem, de verão

Nos anos 1970, o clima da Pré-Amazônia era caracterizado como equatorial quente e úmido, uma subdivisão do clima tropical. A temperatura média anual variava de $25^{\circ} \mathrm{C}$ a $27^{\circ} \mathrm{C}$; a umidade relativa do ar era de $80 \%$, enquanto os índices pluviométricos variavam entre 1.800 e $2.000 \mathrm{~m}$. (Silva, 1975).

Estes dados sofreram drásticas modificações ao longo das últimas três décadas, devido à rápida devastação da cobertura vegetal da região: nota-se, claramente, um gradual aumento da temperatura e diminuição das chuvas, o que já acarretou prejuízos sérios às culturas locais, como em 1999.

A vegetação da região, quando da implantação dos dois primeiros núcleos do Projeto de Colonização Agrícola de Buriticupu, podia ser assim classificada e descrita: os igapós, às margens e nas nascentes dos rios, riachos e córregos, com predominância de palmáceas, destacando-se a juçara

2 um dos "projetos de colonização dirigida" (à Pré-Amazônia) do governo do estado do Maranhẫo, que teve vigência entre 1973 a 1987.

3 localizam-se entre os $4^{\circ} 27^{\prime} 22^{\prime \prime}$ e $4^{\circ} 30^{\prime} 00^{\prime \prime}$ de latitude ao sul do Equador, e os $46^{\circ} 35^{\prime 2} 27^{\prime \prime}$ e 465'03" de longitude ao oeste de Greenwich (Silva, 1975). 
(Euterpe edulis Mart.) e o buriti (Mauritia flexuosa) - como já sugere, aliás, o próprio nome da localidade; as várzeas, que se manifestam nos interflúvios; as matas de terra firme, próprias das partes mais elevadas, com árvores grandes e frondosas, com até 50 metros de altura, destacando-se a grande variedade de madeira de lei (Universidade Federal do Maranhão, Fundação Nacional de Saúde/Coordenação Regional do Maranhão, 1994).

Devastada, de imediato, pela exploração descontrolada dessa madeira, posteriormente pela abertura de pastagens para os grandes empreendimentos de pecuária extensiva, assim como pela agricultura de "coivara" praticada pelos pequenos lavradores, essa mata recuou e já está distante a bem mais de 100 quilômetros da sede do município de Buriticupu (núcleo inicial do Projeto de Colonização), segundo relato de moradores locais. Os arvoredos que se observa nos vales das imediaçôes constituem-se, em realidade, numa "capoeira", resultante, possivelmente, de uma única etapa de desmatamento - e que, por já apresentar um certo adensamento, poderiam ser confundidos com a mata primitiva. Constata-se, no entanto, que se trata de uma cobertura secundária, sobretudo em função das espécies ali encontradas, a exemplo da grande incidência de imbaúba (Cecropia sp). No entanto, existem áreas, nas maiores elevaçôes topográficas, onde ainda restam alguns capões da vegetação primitiva que demonstram como teria sido a vegetação original da região.

Assim como a flora, a fauna da região, que apresentava quase todas as espécies amazônicas, praticamente desapareceu, em decorrência da predação. Raramente ainda podem ser encontrados animais de médio porte, como o tamanduá (Myrmecophagidae sp), predominando os animais de pequeno porte, como o tatu (Dasypodidae sp), a paca (Agouti paca), a cutia (Dasyprocta aguti), o jabuti (Geochelone carbonaria) e outros répteis, habitantes de vegetação mais baixa, como a dos cerrados (Universidade Federal do Maranhão, Fundação Nacional de Saúde/Coordenação Regional do Maranhão, 1994).

Sob impacto dos projetos de desenvolvimento, das madeireiras, dos latifúndios, dos grandes empreendimentos agropecuários e da lavoura de "coivara", a floresta vem recuando rapidamente. Os projetos de desenvolvimento e os grandes empreendimentos agropecuários, desalojando levas de pequenos lavradores sem-terra (ou, melhor dizendo, sem títulos de terras), pressionam-nos constantemente contra as matas ainda preservadas e as terras indígenas (de modo geral, menos protegidas e de acesso mais fácil que os latifúndios), de modo que sua agricultura itinerante, que utiliza a derrubada e queima da mata para a limpeza das áreas de cultivo - a "coivara" - técnica herdada dos próprios índios (que a praticam, no entanto, de modo sustentável, associada ao revezamento das terras exploradas, no interior de um território circunscrito), embora em pequena escala, termina incorporando-se e desempenhando um papel significativo nesse modelo exploratório, abrindo caminho para a contínua expansão dos latifúndios.

À maneira do que se passou com a quase totalidade dos povos indígenas no Brasil, os povos indígenas no Maranhão que sobreviveram às sucessivas açōes de extermínio executadas por portugueses, brasílicos e brasileiros, todos, sem exceção, sofreram drásticas reduções e alterações em suas "terras tradicionalmente ocupadas" (a que a Constituição da República Federativa do Brasil de 1988 lhes assegura o direito - cf. Capítulo VII, art. 231), pelas sucessivas frentes de expansão e formaçôes sociais que as envolveram, no processo de consolidação do Estado brasileiro.

\section{MATERIAIS E MÉTODOS}

O presente trabalho resulta de pesquisa de doutorado (Varga, 2002), e de pesquisas de campo em andamento (projetos "Indicadores de qualidade de vida de comunidades rurais, quilombolas e indígenas, na Pré-Amazônia", "Conservação e revitalização participativa da bacia do rio Buriticupu", e "Coletivos educadores: alternativa sustentável e solidária aos povos do cerrado e da Pré-Amazônia maranhense." $)$ ), em que recolhemos depoimentos de trabalhadores rurais, índios e quilombolas, habitantes da região.

Constituindo-se em fontes às quais as pesquisas em Etnografia indígena por vezes não recorrem às memórias e depoimentos de trabalhadores rurais (não-indígenas) aportam indícios e informaçôes que podem enriquecer os conhecimentos já disponíveis acerca das relações entre grupos indígenas, chegando a ser elucidativos a seu respeito, sobretudo quando estas estão marcadas por tensões, conflitos abertos - ou mesmo alianças, como se verá neste trabalho.

\section{POLÍTICAS AGRÁRIAS, TRABALHADORES RURAIS E ÍNDIOS: RELAÇÕES INTERÉTNICAS NA PRÉ- AMAZÔNIA}

\section{OS TENETEHARA/GUAJAJARA E 0 VALE DO PINDARÉ}

Os Tenetehara formavam uma etnia relativamente homogênea, que habitava todo o vale do rio Pindaré (cf. Wagley e Galvão, 1961; Gomes, 2002; Zannoni, 1999).

São ainda do tempo da tentativa francesa de colonização do Maranhão os primeiros relatos de contato com os Tenetehara;

4 Financiamento pela Coordenação de Aperfeicoamento o Pessoal de Ensino Superior (CAPES)/PRODOC do Ministério da Educação (MEC), e Universidade Federal do Maranhão (UFMA)/Mestrado em Saúde e Ambiente (MSA).

5 projeto em execução, em parceria entre o MSA/UFMA e a Prefeitura Municipal de Buriticupu, a ser encaminhado ao Fundo Nacional do Meio Ambiente, do Ministério do Meio Ambiente.

6 projeto do Centro de Educação e Cultura do Trabalhador Rural (CENTRU), com financiamento a ser articulado pelo Ministário do Meio Ambiente. 
logo após a fundação de São Luís (1612), uma pequena expedição foi enviada ao Pindaré, de onde retornou com notícias de uma numerosa nação indígena a que denominaram de "Pinariens". Expulsos os franceses em 1615, Bento Maciel comandou a primeira expedição portuguesa ao Pindaré, em fevereiro de 1616. Já com uma atitude francamente belicosa, sua expedição em busca de ouro desencadeou um longo período de massacres, escravização e guerra aberta com os Tenetehara, que perduraria até meados do século XVIII.

Dentre os grupos indígenas que atualmente habitam o Maranhão, os Tenetehara também foram os primeiros a ser contactados e atraídos pelos jesuítas, já em meados do século XVII. Inaugurava-se assim, em 1653, com a chegada do Padre Antônio Vieira (Superior dos jesuítas) ao Maranhão, conforme proposto por Gomes (2002), a fase da "servidão" dos Tenetehara aos jesuítas, que perduraria até 1759 , quando de sua expulsão do Brasil.

Em 1680 eram implantados, pelos jesuítas, os primeiros aldeamentos Tenetehara do então Estado do MaranhãoGrão Pará, às margens do lago de Viana, na chamada Missão Maracu.

Para fugir inicialmente dos portugueses caçadores de escravos, depois dos fazendeiros e senhores de engenho e, finalmente, do servilismo e do controle praticado pelos jesuítas em seus aldeamentos, parte dos Tenetehara migraram para as matas do oeste (os Tembé, que viriam a atravessar o rio Gurupi em meados do século XIX, passando a habitar terras do estado do Pará - cf. Sales, 1993), enquanto os demais permaneceram ocupando os vales e o interflúvio entre os rios Mearim e Grajaú (Guajajara), expondo-se, assim, às conseqüências de um convívio mais precoce com as sucessivas frentes de expansão da sociedade envolvente.

Em 1759, os jesuítas foram expulsos do Maranhão, do Brasil e de todas as colônias portuguesas.

Os Guajajara passaram, assim, a ser alvo de uma política de miscigenação intensiva, executada pelos "Diretórios" nos aldeamentos ao longo dos rios Pindaré, Mearim e Grajaú (Conselho Indigenista Missionário-Regional Maranhão, 1988), que substituiu o sistema de servidão aos jesuítas pelo da "patronagem" ou "clientelismo" com os fazendeiros e comerciantes locais, fundado no estabelecimento e no aprofundamento da dependência do "cliente" para com seu "patrão". Para Gomes (2002) este sistema viria a caracterizar as relações dos Tenetehara com a sociedade envolvente, durante todos os séculos XIX e XX, até nossos dias.

As primeiras décadas do século XIX transcorreram sem que se registrasse eventos ou medidas de maior destaque no campo do relacionamento da sociedade regional com os Guajajara.

$\mathrm{O}$ ano de 1840 representou um marco na retomada, já no contexto imperial, do incremento da política clientelística para com os Guajajara. Neste ano, o Tenente-Coronel do Imperial Corpo de Engenheiros, Fernando Luis Ferreira, foi enviado ao baixo Pindaré, pelo Coronel Luís Alves de Lima e Silva (futuro Barão e Duque de Caxias, então no comando das tropas que combatiam a Balaiada), para elaborar e colocar em execução um "plano de civilização" para os Guajajara, visando assegurar a defesa da região contra incursôes dos rebelados, e que os índios não viessem a aderir a eles. Este plano resultou na criação da Colônia São Pedro do Pindaré (Marques 1970, p. 206). Várias outras "colônias" viriam a ser criadas nos anos seguintes, abrangendo outros grupos Guajajara: Colônia Januária (1854), Aratauhy Grande, Palmeira Torta e Dous Braços (entre 1870 e 1873).

Em 1860, os trabalhos de abertura da "Estrada da Boiada" também chamada de "Estrada do Sertão" (partia de Carolina, passando por Grajaú, margeando inicialmente o rio Buriticupu; na década seguinte, seria desviada para margear o rio Zutiwa, em terreno menos alagadiço), ligando as frentes pecuaristas do sul ao mercado consumidor da capital, mobilizou muitas famílias Guajajara da região de Grajaú que, a partir de seu funcionamento, em 1863 (Marques, 1970), passaram a trabalhar como guias de rebanho ou em lavouras dos fazendeiros da região, instalando suas aldeias ao longo da Estrada. Deste modo, as relaçôes interétnicas e de troca dos Guajajara desta região (designada por Gomes 2002, de "Grajaú-Barra do Corda") com a sociedade envolvente consolidaram-se, a partir das últimas décadas do século XIX, no universo sócio-econômico da pecuária e da agricultura regionais (sobretudo de algodão, arroz e mandioca).

Já os Guajajara da região do baixo vale do Pindaré, assim como os Tembé do Gurupi, desenvolveram suas relaçôes com a sociedade envolvente no contexto da economia extrativista, mediada pelos regatões (baseados inicialmente na Colônia São Pedro, e depois na Colônia Pimentel, até a década de 1950), cuja produção mais significativa era o óleo de copaíba.

Em 1897, os capuchinhos (franciscanos) da Lombardia fundavam a Missão de São José da Providência do Alto Alegre, num sítio localizado nas proximidades de várias aldeias Guajajara, iniciando uma tentativa de catequização e colonização dos índios da região de Barra do Corda (em que predominavam, numericamente, os Guajajara). As estratégias adotadas pela Missão de Alto Alegre consistiam na atração dos índios a instalarem suas aldeias mais para perto da missão, de modo a envolvê-las nos trabalhos de suas lavouras de algodão e cana-de-açúcar (que assegurariam sua viabilidade econômica), e na promoção de uma miscigenação cultural, orientada pela catequese capuchinha, que se concentraria junto a meninas com menos de 14 anos, procedentes tanto de povoados regionais quanto de aldeias indígenas, que seriam envolvidas num convívio diuturno, incorporadas à missão em regime de internato. 
No que se refere aos índios, tratava-se de, literalmente "desmembrar as aldeias indígenas e reduzi-las a grupos familiares", de modo a organizar uma próspera "cidade de índios" - conforme consta no livro de correspondência da própria Missão (Gomes 2002) - integrada à economia da região.

Do ponto de vista econômico, o povoado de Alto Alegre prosperou rapidamente, de fato, destacando-se, na região, por sua produtividade.

Após um surto de varíola e um de tétano que, em janeiro de 1900 vitimaram 28 das 82 meninas índias internas e alguns episódios de punições mais severas ou mesmo violentas aplicadas pelos missionários aos índios, os quais puniam severamente, por exemplo, os casos de poligamia, e internavam as crianças na missão, retirando-as forçosamente do convívio com os pais (Gomes, 2002), sua insatisfação foi crescendo rapidamente, até que em 13 de abril de 1901 eclodia uma rebelião de grandes proporções que culminou no massacre dos religiosos, conhecida como "rebelião de Alto Alegre", que resultou em centenas de vítimas, entre índios e regionais.

Derrotados e massacrados, após renhida resistência, pelas várias expediçôes militares contra eles enviadas a partir de Barra do Corda e Grajaú, mesmo após a tortura e morte de Kawiré Imàn (conhecido pelos missionários e pelos regionais como João Caboré, e por eles considerado o líder da revolta), os Guajajara continuaram sendo, por longo tempo, perseguidos e sistematicamente agredidos pela população regional, como conseqüência desta rebelião.

Para Gomes (2002), a Rebelião de Alto Alegre "constitui o diferencial entre os Tenetehara da região de Barra do Corda-Grajaú e aqueles do Pindaré-Gurupi”, uma vez que, para este autor, as aldeias que participaram da rebelião (das TIs Canabrava-Guajajara, Urucu-Juruá e Bacurizinho) "constituem hoje o centro propulsor da afirmação étnica e da participação política dos Tenetehara”.

Em 1910 era criado o Serviço de Proteção aos Índios e Localização de Trabalhadores Nacionais (SPILTN). Em 1918, o SPILTN teve suas atribuições repartidas entre dois outros órgãos, sendo que a política indigenista passou a ser atribuição do Serviço de Proteção aos Índios (SPI).

\section{FRENTES DE EXPANSÃO E MOBILIZAÇÃO DE TRABALHADORES RURAIS NO VALE DO PINDARÉ}

\section{CICLOS DO CANGAÇO, CORONELISMOS: ANOS 1920-1930}

A região atravessava, à época, intenso afluxo de imigrantes nordestinos. Já em 1912, com o fim do chamado segundo ciclo da borracha no Brasil, levas de nordestinos a caminho da Amazônia detiveram sua marcha e assentaram-se a meio-caminho, em terras maranhenses (Droulers \& Maury, 1981).

Em 1920, a frente pioneira nordestina posicionava-se a oeste de Codó, na cidade de Pedreiras (Araújo, 2000).

Pequenos lavradores imigrantes nordestinos começaram a adentrar as matas do baixo Pindaré no início dos anos 1930. Segundo depoimento do Sr. Pedro Marizê (liderança Guajajara da aldeia Juçaral, da TI Araribóia - (Varga 2002), durante a década de 1930 os Guajajara do alto Pindaré passaram a receber visitas mais freqüentes de comerciantes de peles de animais e de caçadores regionais que, utilizando-se da Estrada do Sertão, faziam pouso próximo à aldeia Tauari Queimado. Guajajara habitantes de várias outras aldeias (como Genipapo, Queimadas, Parinanaua) também mudaram-se para a do Tauari Queimado, de modo que, ao final da década, esta já abrigava cerca de 400 pessoas, quando instalou-se na região uma missão de evangélicos ingleses (seus primeiros moradores não-indígenas), cuja casa foi cercada por arame farpado (material relativamente raro na regiáo, naquele tempo) - de onde provém o nome "Arame" do povoado que ali começou a se formar (Gomes, 2002).

Os relatos de trabalhadores rurais sobre o período revela episódios surpreendentes sobre seu contato e aliança com os índios, e sobre seus conflitos com os fazendeiros, dos quais não encontramos qualquer registro na literatura etnográfica sobre os Guajajara:

“(....) aqueles velhos mais antigos - lá cinqüenta anos éconsiderado já velho, não do ponto de vista da idade, mas do ponto de vista do físico: o cara está acabado - diziam assim:

- Me lembro muito bem de uma luta que se deu aqui. Eu penso que foi antes de 1930. Na época, os indios estavam sendo expulsos das matas encostadas no Pindaré-Mirim por esses donos que estão ai hoje. Diziam que eles faziam mal, eram bichos selvagens." (Conceição, 1980, pp. 96-97).

"E... e a razão era o que: era porque, lá... o nome de Pindaré, antigamente, se chamava Engenho Central. Lá no Engenho Central, que foi o primeiro engenho que fez açúcar branco no Maranhão, esse açúcar branco, né, era feito lá. Tá entendendo? E os indios... dizem eles lá, que eram pego, porque pegavam cana, lá, lá do Engenho, do plantio né, e aí, tiravam o caldo, e chupavam o caldo, e tomavam o caldo e... fazia quizila na lucração deles, né, não é isso?... E botavam eles pra... pra perseguir os indios... Eai os indios se revoltavam... [...] Por causa da questão da... da cana, que eles não queriam que os indios mexessem. Que os indios já viam como terra deles... Que o Pindaré era terra indígena, de muitos anos. Era terra indigena, antigamente. Ai os indios... Né?... Podiam aproveitar, pelo menos... o que tava lá na... na produção [risos]... eles eram meio revoltados, né..." (entrevista com Manoel da Conceição, 25/5/2005). 
Destes relatos, reproduzidos por Manoel Conceição Santos ${ }^{7}$, mais conhecido como Manoel da Conceição, emerge (o ainda muito pouco conhecido e pesquisado) Antônio Bastos:

Sem maiores sucessos nas pesquisas de fontes a respeito de Antônio Bastos (além de Conceição, 1980), seguem os esclarecimentos que pudemos obter a respeito, na entrevista citada:

MANOEL DA CONCEIÇÃO - "Pois é, meu companheiro... Essa história, quando eu era rapaz, jovem, já ouvia falar nela, pelos meus bisavós, que isso aconteceu oito ou dez vezes... E... eles contavam, que esse Antônio Bastos, era um companheiro muito sabido... sabia ler muito bem... e escrever ... era um doutor! Assim... Que na época não sei se era doutor mesmo, que eles chama né, diz que ele era conhecido como doutor... Antônio Bastos."

E. - "E diz que ele escrevia, né?"

MANOEL DA CONCEIÇÃO - "Ele escrevia muito! Diz que era um cara bom de caneta, bom de caneta! Diz que tinha contato com... com São Luis, e etcétara."

E. - "Mas ele era jornalista?"

MANOEL DA CONCEIÇĀO - "Não, não sei. Só que era Antônio Bastos o nome dele. Antônio Bastos. Agora eu não sei se era jornalista, agora eu não sei..." (entrevista com Manoel da Conceição, 25/5/2005)

Segue a descrição das ações dos Guajajara e de Antônio Bastos (note-se que não se trata de simples assaltos, ou de açôes simplesmente violentas ou depredatórias):

"Quando os indios estavam bem sabendo quem eram os inimigos, começaram a invadir Pindaré-Mirim. O estardalhaço que eles faziam era coisa de admirar. Primeira medida: prendiam o prefeito com toda a policinha local. Raspavam a cabeça, tocavam na cadeia. Nesse tempo, Pindaré-Mirim só tinha o rio como comunicação para São Luís. Vinha lancha com muita dificuldade, enfrentando coivaras de pau: passava quase meses pra chegar. Depois que eles prendiam as autoridades municipais, os indios invadiam os armazéns que tinham roupa, tecidos, ferramentas de trabalho, espingarda de caça e comida. Distribuíam não para os indios, mas para a população pobre. Isso era uma confusão desgraçada. E a massa começou a se candidatar também. Junto com os indios, pra ficar ao lado de Antônio Bastos. O fato é que eles fizeram isso umas oito vezes, segundo os antigos, no periodo entre 1920 e 1930." (Conceição, 1980, p. 96-97).

Finalmente, o assassinato de Antônio Bastos, com requintes de crueldade:

"Agora, sabe o que aconteceu com Antônio Bastos? Um dia, ele adoeceu nas matas e não teve jeito pra se tratar por lá. Veio

7 lavrador e ferreiro, atual Presidente do Centro de Educação e Cultura do Trabalhador Rural (CENTRU) do Maranhão, foi a mais importante, expressiva e conhecida lideranca dos movimentos dos trabalhadores rurais do vale do Pindaré, ao longo dos anos 1960 e 1970. escondido se tratar no município que chama Vitorino Freire, porque tinha um hospitalzinho. Mas souberam que ele estava lá e mandaram buscar o homem. Chegaram aqui na encruzilhada entre Cajueiro Grande e Santa Inês, e nós escutamos os tiros de bacamarte. Trouxeram o homem até a terra dele, pro povo ver que ele tinha sido morto. Enfiaram três grandes estacas no chão. Tudo de ponta fina. Meteram nas palmas da mão dele. Espicharam assim, bem no centro do caminhozinho e enfiaram outra estaca aqui debaixo do queixo. Deixaram ele lá de braço aberto, espetado na ponta de três estacas e depois arrancaram a língua, pra ele deixar de ser falador. Diziam que a lingua dele ninguém podia vencer, porque ele fazia tudo com a lingua. E as mãos espetadas era porque aquele homem escrevia bem." (Conceição, 1980, pp. 96-97)

Morto Antônio Bastos, a crueldade da dominação dos "coronéis" do Engenho Central, já decadente, continuaria a deixar várias marcas lúgubres na memória dos trabalhadores rurais da região:

MANOEL DA CONCEIÇÃO - “O Engenho Central se acabou... mas ficou lá a tocha do tonelzão lá, de cana, alto! De tijolo... E dizem mais uma coisa, que contavam na época né [...] depois que o Engenho faliu... que ficou só... porque o Engenho tinha um... um sangrador pro rio... porque o pessoal... toda a parte chamada braseiro do engenho, essa coisa toda, ia cair tudo no rio, né. Elá na frente do rio, lá tinha uma grade de ferro que... era feita assim... de ferro roliço né, é... um... uma grade, que não passava uma pessoa não. Então disseram lá, contavam lá também, que muitas pessoas que os homens lá odiavam, prendiam, ia pra lá pra fornalha do Engenho Central, metia o cara no buraco, que ia sair no rio, mas não podia sair lá porque tinha grade de ferro, né, ai tampava a boca, e o cara morria dentro, trancado lá. E diz que até isso ai até com os indios, também, indios. Quando pegavam os indios faziam isso também lá. E pegava eles indios mesmo e morria e jogava lá dentro. Em vez de matarem... botavam cá no buraco e tampava, pronto: ninguém sabia. O cabra morria de fome, no buraco lá... de sede... e dos maus tratos né. Então, nesse tempo havia muito isso. E, me diziam que lá tinha uma familia, chamada família Maluf, tá entendendo?... Que era um dos mais ricos da região, que era um dos que praticavam esse tipo de ação. Agora o nome dele, é Maluf, mas é Tufi Maluf. O nome do homem lá. Esse que fazia isso, né."

E. - "Dai que vem Tufilândia, ne?"

MANOEL DA CONCEIÇÃO - “É, Tufilândia, esse lá tudo fica povoado de Tufilandia. Essa Tufilândia, essa lândia, vem desse desgraçado lá Maluf. Aí, por aqui todo canto tem lândia, mas ninguém não sabe. Se você perguntar a qualquer pessoa aqui, de onde é que vem a lândia, ninguém não sabe. Agora tem essa Tufilândia lá [risos], desse Tufi Maluf lá [...] que era o mandachuva de toda a região aqui, era ele, né, que era o dono das estrepolias. Ele não era nem brasileiro, assim, nato, de origem brasileira. Ele era de origem internacional. Chamavam também 
de carcamano, né... [...] Eu sei que ele era o mandachuva de lá, né. E ele fazia isso. Então, dizem que ele liderava essas coisas."

[...]

E. - Então, você imagina que tenha sido ele o mandatário, né, da morte do Antonio Bastos.

MANOEL DA CONCEIÇÃO - Não, eu... acho que não foi nem ele. Acho que foi os descendentes [querendo dizer os antepassados] dele, quer dizer... ele é originado pelaí.. Deve ter sido os pais dele, os avós dele... eu sei lá quem diabo foi... acho que foi... acho que não foi ainda do tempo do... do Maluf... o Maluf era um cara ainda novo... Agora, o Malufera filho desses, dessa família né, que mandavam no Pindaré, e que depois ficou mandando. Mas quando eles mandavam, o Engenho já tinha... já tava, já tinha falido lá. Já... já tava mais manso, na época do Maluf. Mas mesmo assim ainda fazia isso: pegava gente e metia lá no buraco do... do Engenho Central. Mas o Engenho Central já tinha se acabado, a muito tempo. Mas, eu creio, que como é uma... uma... coisa histórica, se você for lá, ainda deve ter a torre lá..." (entrevista com Manoel da Conceição, 25/5/2005)

À franja do carro-chefe da economia agrária brasileira, o sertôes da pecuária nordestina (inclusive os do Maranhão, assim como seus canaviais e algodoais) foram relegados a um segundo plano pela política de desenvolvimento da Primeira República. O governo federal privilegiaria investimentos no pólo mais lucrativo da cafeicultura (sobretudo na então mais modernizada, do oeste paulista), e privilegiaria a interlocução política com os seus representantes (Eid, 1979).

As secas passam a estabelecer diferenças intra-regionais, na medida em que determinadas áreas, mais imunes às secas e mais aptas às produçōes alternativas, tornam-se concentradoras de mão-de-obra, como o vale do Cariri (em que Padre Cícero incentivou a cultura da maniçoba), o médio São Francisco (com a produção de ceras vegetais), Lavras Diamantina (na Bahia) e os vales úmidos do Maranhão.

Estes fluxos foram estimulados, tanto pelos governos dos estados de origem dos emigrantes (como válvula de escape para seus conflitos sociais internos) quanto pelos de assentamentos imigrantes (como contingentes para o "desbravamento" dos sertōes e das matas - caso do Maranhão); nestas regiōes estabeleceram-se relaçóes de trabalho distintas das dos latifúndios canavieiro e algodoeiro (Eid, 1979).

É deste período a profecia das "bandeiras verdes", referência presente em vários depoimentos de posseiros vindos do Piauí para o Maranhão e para a região do Bico-do-Papagaio (norte do atual estado de Tocantins), entrevistados por Sader (1986): Padre Cícero teria dito, no Cariri, que "quando a situação piorasse, os fiéis deveriam partir, atravessar o grande rio e buscar as Bandeiras Verdes" (pp. 106-107).

Este é, portanto, o cenário social, econômico e político do chamado "ciclo do cangaço" nos estados do Nordeste.
Há consenso entre pesquisadores quanto ao Maranhão não ter sido envolvido no chamado "ciclo do cangaço" que, no período 1920-1930, ter-se-ia restringido aos estados de Pernambuco, Ceará, Paraíba, Rio Grande do Norte, Alagoas, Sergipe e Bahia.

Discutindo o coronelismo e suas estreitas relações com o cangaço, Dória (1982) comenta como os coronéis dos anos 1920 e 1930 foram incorporados aos novos blocos políticos, alinhados com o eixo econômico hegemonizado pelas elites do Sudeste e do Sul.

Embora referindo-se aos estados do Nordeste que foram palco do cangaço, entendemos que as observaçôes de pesquisadores como Durham (1973), Dória (1982) e Eid (1979), também aplicam-se ao Maranhão deste período.

Durante as duas últimas décadas do século XIX, os investimentos de capital na agricultura do Maranhão experimentavam um processo de dispersão, findo o segundo surto algodoeiro, voltando-se, sobretudo, ao mercado consumidor interno. Ao lado da pecuária sertaneja, começava a ganhar impulso e importância a rizicultura e o extrativismo do babaçu ${ }^{8}$.

O tecido social no Maranhão rural, ao longo de todo o século XIX até a década de 1950, manteve-se assentado sobre a mesma ordem clientelístico-patronal, tanto no caso de comunidades indígenas quanto nas de trabalhadores rurais.

Acirravam-se as tensóes e a violência dos conflitos entre os grandes latifundiários (e os vaqueiros jagunços a seu serviço) e os pequenos lavradores sem-terra e coletores de babaçu.

Em sua juventude, Manoel da Conceição foi dos trabalhadores rurais que, além do trabalho na roça, no baixo Pindaré, teve a oportunidade de dedicar parte de seu tempo à caça e à pesca, no alto vale do rio, privando de convívio amistoso com comunidades Guajajara da região, em fins da década de 1950.

"...o nome dele era Raimundo Fonseca, o nome do capitão dessa aldeia. Ai... o Raimundo Fonseca falava português. Ai, se comunicou conosco, lá e..., e aí... a gente foi lá pra aldeia, né. E lá... ficamos lá... uns 30 dias, nessa aldeia. Comendo farinha, fazendo farinha mais eles, lá... e... caçando... nas matas... muitas vezes um caçava, nas matas... e às vezes ia pega peixe... E... é assim... parece que... nessa época. Isso foi, pra precisar bem a data... que isso aconteceu, isso foi de... 58, aqui no Pindaré-Mirim..." (entrevista com Manoel da Conceição, 25/5/2005).

Em Conceição (2000), o mesmo Manoel da Conceição discorreu sobre as relaçōes amistosas que ele e membros de sua comunidade (e outras) de trabalhadores rurais do baixo vale

8 Na perspectiva de revitalizar o capital estagnado com a desaceleração dos investimentos na cotonicultura instalava-se, ao final do século XIX, um grande parque têxtil em São Luís, localmente chamado de "Manchester brasileira". A indústria têxtil no Maranhão, no entanto, também não conseguiria competir, no mercado nacional, com a que vinha se formando no Sudeste (Gonçalves, 2000, p. 127; Varga, 2002, p 78). 
do Pindaré cultivavam com essas comunidades Guajajajara do alto vale do rio, à época. Prosseguindo a entrevista acima, transcrevemos trechos em que discutimos, consigo, partes deste livro:

MANOEL DA CONCEIÇÃO - "É eu era ferreiro, nessa época!...” [...] "... os indios vinham lá dos... dos cafu do PindaréMirim, né, dos espinhos, das matas, né. E quando vinha, trazia as armas deles de caça, né, espingarda, né, e coisa... Aí.. eu... eu passei a ser ferreiro deles! Trazia as armas velhas deles lá, tinha aquela "foreigner", eles trazia lá... e eu a sabia fazer tudo aquilo, né, fazia tuudo direitinho!... Remendava... aqueles que elas caçavam... até facão..."

E. - "E era o pessoal dessa aldeia aí?..."

MANOEL DA CONCEIÇÃO - "Essa aldeia, que passaram a ser meus amigos. Quando eles desciam para o Pindaré, com produção, esses couro de caça, pra vender... Couro de ariranha, couro de gato, couro de onça, né... Eles matavam, tirava o couro e vendia. O capitão, que tava lá, era indio. Mas ele teve muito tempo aprendendo a ler, lá em... Pindaré-Mirim. Aí com... carregava o povo pra lá, né. Ai criava aquele vínculo, entre ele e a aldeia. Ai o cabra ele andava demais: ele andava, às vezes, semana inteira, pra chegar nas aldeias, assim, do Pindaré, na canoinha... Eagora, o... chega lá no comércio, o capitão fazia negócio pra todos eles, né. Era só pra ajudar os outros, mas... quem fazia negócio lá era o capitão. Era o capitão que falava tudo, né, falava português [riso]... e ele que fazia os negócios dos indios. Ele mandava fazer a... arrumar o cabo de espingarda, as coisas, né... os facão, as ferramentas... a enxada, a foice... tudo né? O machado... Tudo eu fazia lá... lá em casa... Em Tufilàndia, que hoje é cidade." (entrevista com Manoel da Conceição, 25/5/2005)

Finalmente, comentários de Manoel da Conceiçãao acerca da relação desta comunidade Guajajara, de Capitão Raimundo Fonseca, com grupos Awa ("Guajá") que perambulavam pela região. Competindo pelo espaço com aquela comunidade Guajajara, grupos Awa serviam-se, com alguma freqüência, de parte das roças dos Guajajara, até que um casal Awa terminou feito prisioneiro dos Guajajara:

Manoel da Conceição - "Tinha uma mulher indígena, índia né, e tinha um homem, que era Guajá. E estas mulher... esta mulher, e este homem... rapaz!... Era, assim, uma escravidão danada. Porque eles... diziam que eles estavam presos... porque não trabalhavam, não plantavam mandioca, não fazia roça... na... só queriam viver do suor deles, né... Então eles pegavam e escravizavam, lá.

Os Guajajara tinham lá uma rocinha que eles faziam lá, plantavam mandioca, e fazia farinha, fazia tapioca, né... E os Guajajara... os Guajá, né... vinha só... usufruía, né... e pegava a mandioca, né... e entrava no mato... pra ir comer lá... na aldeia da... lá no mato!... [risos]. Pra fazer, do outro lado, a farinha, né, pra eles fazer também... Mas não sei como é que eles faziam... $[\ldots]$
Ai resultado: eles é quem cozinhava... chegava com a caça, os outros ia descansar, eles iam cozinhar... cortava... a carga todinha na palmeira... depois botava pra cozinhar, depois distribuir... Tá entendendo?... Eles é quem ia lá fazer a farinha lá na... lá no... na casa que tinha um forno... eles iam lá fazer a farinha, a mando deles... Quando matava uma caça, lá por cima, um capelãozão, aí dizia: rapaz, agora tu vai subir lá encima... Que aí, atirava no capelão, e ele ficava enganchado lá encima... [...] ficava enganchado lá no cipoal, lá encima, nos outros paus... aí, ele é que tem que subir, né, no cipó, né, e se... até chegar no cipoal pra desenganchar e jogar no chāo. E ele que carregava também as caças que... que matavam, né. Ele que carregava as caças... Tá entendendo?... Só quando não é muito grande... se é uma caça, assim, um veadinho, um tatu, um capelāo, um macaco... aí ele que carregava tudo na... na... nas costas. Era assim. Ai é como disse: aquele é escravo! É escravo porque? Porque eles não quer trabalhar, plantar mandioca, não quer... não sabe fazer roça!... Só querem comer da nossa!... Isso quem me explicava era o capitäo dessa aldeia, né. Lá chamava capitão, o chefe das aldeia, né. Aqui é cacique. Lá chamava capitão. Capitão da aldeia."

E. - "Mas, assim, não... não havia tentativa deles fugirem, desses Guajá fugir também, dos... Guajajara?..."

MANOEL DA CONCEIÇÃO - "Não, não tinha como fugir não, era bem vigiado!... [...] Aldeia grande, né, tinha umas 50 famílias de... de... de indios lá, né... e... não tinha como fugir não. Ficavam lá vigiados... [riso]. Mas vigiados mesmo!..."

E. - "Mas você não chegou a ver eles apanhar..."

MANOEL DA CONCEIÇÃO - "Apanhar, não. Apanhar nunca vi! Eles trabalhavam como escravo, né, assim... pra ganhar... pra ganhar comida... E... Era só isso mesmo. Se eles tinham medo de fugir?... Não sei porque... porque os outros... talvez não arredava mais eles... não sei... Só sei que eles não deixavam... eles não saíam de lá. Ele era vigiado."

E. - "Era vigiado como? Tinha alguém pra olhar eles?"

MANOEL DA CONCEIÇÃO - "Tinha... tinha pra vigiar eles, né... Eles não tava... nunca tavam sozinhos. Eles sempre tavam lá acompanhados de outros 2 ou 3 indios. Mas não andavam amarrados, não. Ficava solto. Nenhum. Nenhum não era amarrado não. [...]. Era tudo solto. A diferença que tinha entre eles, é que os indios Guajajara tinha o capitão que era um intérprete, lá, porque ele falava português, muito bem. Agora, os outros, ninguém falava português. Somente... E nem tamp... E também, os Guajajara... não, os Guajá... não tinha intérprete. Tá entendendo?"

E. - "Mas eles entendiam bem o que os Guajajara diziam pra eles?"

MANOEL DA CONCEIÇÃO - "Ai eu não sei... ai eu não sei porque... eu não... eu não falava com nenhum... eu não entendia a lingua de nenhum dos dois." 
E. - "Você via os Guajajara falando com os Guajá?..." MANOEL DA CONCEIÇÃO - "Via, mas assim em aceno, né... fazendo lá... Mas mais em aceno... Assim, falando mesmo não via não. Mas era mais em aceno... acenando... Ó: a caça, né... trazia aqueles moqueados pra eles fazer, né, e fazia lá. E disse... que já sabia, né... que aprendeu com os outros parentes lá, né, esses indios lá já... já tava acostumados com... com os... Guajajara, né, Guaj... estes dois Guajá, a mulher e o homem, já estava acostumado já muito tempo lá. Mas todo tempo de escravo! $N e ́$, tava bem domado, assim... acostumado com os outros já. Aí não sei se eles tinham assim um indio dono do outro." (entrevista com Manoel da Conceição, 25/5/2005)

Comentários sobre as grandes diferenças entre os Guajajara e os Awa:

"Por que tinha uma diferença muito grande... Porque os Guajajara lá, já tinha um grau... já tinha... esse capitão, que falava português, né... e os... os Guajá não tinha... eles lá não... não se comunicavam com comunicar com... com... com nós, né, que eles chamam de branco... não se comunicavam com os brancos, porque não sabiam falar a lingua.

E outra coisa: eles também não tinham ainda, a chamada é, é... roupa... os homens andavam tudo nu! Os Guajá. Tudo peladão! E os Guajajara, já usavam roupa. Assim, né, as mulheres botava uma saiotinhazinha de pena..., às vezes de... saia de tecido de algodão, que eles plantavam lá, né, tinha a rede de embira... ai fazia aquela saiotinha. E os homens, a maior parte era tudo nu. Também os Gua... Guajajara era tudo nuzão! Agora os Guaj... os Guajá, os Guajarra... os Guajá, é que era... tudo, mulher e homem, tudo nu. Não tinha diferença entre eles lá não." (entrevista com Manoel da Conceição, 25/5/2005)

\section{0-1964}

Em 1941, o Inspetor do SPI, José Maria da Gama Malcher, em viagem pelo alto vale do rio Pindaré, impressionou-se com a dimensão da população indígena da região, decidindo-se pela criação do Posto Indígena (PIN) Araribóia, para prestar-lhe assistência. A localização inicial deste PIN, no entanto, foi motivo de celeuma entre Malcher e o agente sertanista José Olímpio: Malcher queria que fosse instalado na aldeia Tauari Queimado que, além de muito populosa, localizava-se à beira do rio Zutiwa e da Estrada do Sertão, permitindo alcançar as terras dos Gavião e dos Krikati, com relativa facilidade; já Olímpio considerou a localidade Geralda, à beira do rio Grajaú, mais propícia, em termos de transporte (Gomes, 2002, p. 314).

A década de 1940 assistiu a um significativo trânsito de lavradores sem-terra pela Estrada do Sertão, no sentido norte e no sentido sul, em busca de terras devolutas. A Estrada alargava-se, à medida que aumentava o volume e o ritmo de seu movimento, tornando-se a rodovia de ligação entre Grajaú e Santa Inês, passando por Santa Luzia (Gomes, 2002).
Em conseqüência da intensificação do contato com esses migrantes, ao final da década de 1940 e início da de 1950, sucessivos surtos de sarampo alastraram-se pelos vales dos rios Grajaú e Pindaré, vitimando muitas aldeias Guajajara, causando-lhes grande depopulação. Nesta época, aldeia Tauari Queimado também foi desativada, após um surto de varíola que, entre 1947 e 1948, dizimou seus habitantes (cujos remanescentes deslocaram-se para outras aldeias à beira do rio Zutiwa). A localidade deixava, assim, de ser considerada aldeia indígena, constituindo-se no povoado de lavradores migrantes chamados Arame (Gomes, 2002).

Em 1948 o Posto localizado na Geralda foi desativado, em função de vários surtos (malária, sarampo, coqueluche), além de vários casos de sífilis, que ocasionaram a morte de centenas de seus habitantes. A mobilização das duas aldeias Guajajara adjacentes a sua localização inicial, a partir de fins da década de 1970, no entanto, ensejaria um processo de demarcação que se encerraria em 1988, dando origem a TI Geralda/Toco Preto.

Em 1949, João Vieira dos Santos (conhecido na região como João Vaqueiro) e outros migrantes chegaram à localidade de Pau Santo; tendo sido de lá expulsos pelos Guajajara, tomaram a Estrada da Boiada ao norte, chegando à localidade de Batatal onde foram bem recebidos pelo Cacique e Capitão João Francisco de Almeida Batatal, que lhes cedeu terras para cultivar. Com a mudança do Cacique Batatal para Porto dos Índios, este vendeu parte de suas terras para João Vaqueiro (Coelho, 1991). Assim, com a chegada de mais migrantes às terras de João Vaqueiro, três lavradores (Francisco Gomes Guarim, Francisco Marques Baquero e Francisco Sabiá) fundaram, em 1951, o povoado de Santa Luzia (Asselin, 1982; Luna, 1984), em terras da antiga aldeia Guajajara de Anajá.

Também em 1949 o PIN Araribóia foi transferido, por decisão do Inspetor do SPI, Sebastião Xerez, para a aldeia Funil (onde até hoje se localiza), entre as nascentes dos rios Zutiwa e Buriticupu.

Os anos 1950 seriam palcos de uma grande intensificação do movimento migratório de nordestinos ao MA. Do ponto de vista dos índios, além da intensificação do contato com os lavradores imigrantes, o período também seria marcado por uma atuação mais efetiva do SPI no campo da assistência à saúde.

Em 1959 o SPI delimitava, no mapa da região, uma área de 430.000 ha, englobando todas as aldeias abrangidas pelo PIN Araribóia. Iniciava-se assim, com o apoio dos índios, o processo de demarcação da TI Araribóia, que só viria a ser concluído pela FUNAI em 1978, após acirrada “disputa com um exagerado número de mais de 2000 novos invasores e alguns poucos antigos sitiantes" (Gomes, 2002). 
Em 1960, contando com incentivos da Superintendência de Desenvolvimento do Nordeste (SUDENE), o Programa de Povoamento do Maranhão (PPM) atrairia grandes levas de lavradores para o vale do Pindaré, acarretando invasões de áreas indígenas e vários conflitos, sobretudo com os Guajajara do baixo Pindaré.

\section{DITADURA MILITAR}

O golpe militar de 1964 repercutiria diretamente na política indigenista. Em 1967 dava-se a extinção do SPI, substituído pela Fundação Nacional do Índio (FUNAI). A doutrina da "segurança nacional" e sua decorrente estratégia de ocupação dos "vazios demográficos" (que incluíam as terras indígenas), apanágio do discurso desenvolvimentista dos militares, deram lugar a uma onda de construção de estradas, pelo Brasil afora.

Impelida, sucessivamente, pelas construções das rodovias BR 010 e 222, pelo crescimento de Açailândia e Imperatriz, pelo Projeto de Colonização Agrícola de Buriticupu, e pela construção da Estrada de Ferro (EF) Carajás, a frente madeireira promoveu, a partir da década de 1970, uma rápida devastação da floresta amazônica em sua então fronteira oriental: o oeste e sudoeste do Maranhão.

Os impactos sociais e ambientais destes projetos na região foram imensos: dos grandes contingentes de trabalhadores rurais por eles desalojados proveio, segundo pesquisas realizadas pela então Superintendência de Campanhas de Saúde Pública (SUCAM) - que, em 1991, seria incorporada à Fundação Nacional de Saúde (FUNASA) - a maioria dos garimpeiros (e profissionais do sexo, como indicam pesquisas posteriores) mobilizados, em meados dos anos 1980, por toda a Amazônia, devastando e invadindo Terras Indígenas, na esteira da frente garimpeira e das cadeias de transmissão da malária e das doenças sexualmente transmissíveis.

A partir de 1973, vários PINs foram criados para os Guajajara, entre os quais 2 no que é hoje a TI Araribóia: os PINs Angico Torto (à margem do rio Zutiwa) e Canudal (à margem do rio Buriticupu). Segundo Gomes (2002, p. 341), as justificativas para a criação de PINs, nesta época, eram de ordem estratégica, voltados à proteção dos limites das áreas demarcadas, face aos migrantes expulsos das fazendas do leste maranhense, do Piauí, Ceará e de outros estados do nordeste, que vinham sendo atraídos pelos grandes projetos de desenvolvimento.

Nesta época, a construção da rodovia no trecho ArameGrajaú ficara a cargo da empreiteira cearense EIT $^{9}$, que

9 a mesma empreiteira também esteve envolvida, com a Planor, na construcão inacabada da MA-008 (ligando Arame a Paulo Ramos), realizada entre 1990 e 1994 tendo recebido do Governo do Estado, entre 1995 e 1996, a quantia de $R \$ 33$ milhões tendo recebido do Governo do Estado, entre 1995 e 1996, a quantia de R\$ 33 milhỗ
(sem que esta dívida estivesse prevista no orçamento de anos precedentes), o que ensejou representação de peculato, junto ao Ministério Público da União, movida pelo senador Aderson Lago contra a governadora Roseana Sarney. 0 processo foi arquivado pelo Procurador Geral da República, Geraldo Brindeiro, por "falta de provas" (cf. Folha de São Paulo, 9 de setembro de 2001. Atual governo gasta 86 mi com aproveitava o ensejo para também adquirir terras a oeste da TI Araribóia.

Entre 1973 e 1974, várias famílias já tinham invadido e se instalado à margem desta estrada, dentro dos limites da TI Araribóia. O povoado Marajá, assim formado, crescia rapidamente e, em 1975, já contava com 2000 habitantes regionais, de modo que, em maio, o Chefe do PIN Angico Torto notificava seus habitantes da necessidade de abandonarem o local, até o prazo máximo de setembro. Findo esse prazo, quando retornou ao local para exigir sua retirada, acompanhado de vários Guajajara, Mario Daltrozo foi baleado; os Guajajara reagiram e mataram o autor do disparo, ferindo mais dois dos invasores.

Após esse episódio, a FUNAI passou a contar com o apoio da Polícia Federal e, em 1976, toda a margem direita do Zutiwa estava livre de invasores, embora o processo de demarcação só viesse a se concluir em 1978 (Gomes, 2002).

Embora se constituindo numa grande vitória dos Guajajara e dos funcionários da FUNAI que a ela se dedicaram e sacrificaram, a demarcação da TI Araribóia, num total de 413.288 ha., deixou de incluir, em seu perímetro, algumas áreas de uso tradicional dos índios, como a área dita da "Matinha" (até hoje habitada por famílias Guajajara, em convívio tenso com posseiros) e a da lagoa Yrirué (chamada pelos regionais de lagoa Santa Luzia):

"Lagoa... lagoa que pertence nós, ficou fora... que hoje é... é da CITEMA. A lagoa de... a lagoa do Axixá, que fica dentro da al... que fica entre a aldeia Angico Torto e a aldeia Cururu. Em mil e novecentos... e... que em... 1973, o branco colocaram o nome de Santa Luzia. O local que nós faz a pescaria há de muito tempo... Mas o... o Nastácio, que mora, nessa cidade de Arame, chegou nesse local que hoje o nome é Santa Luzia, colocado por ele, mas o nome mesmo, era conhecido, por nós indios, Yr'rué, a lagoa da... a lagoa do Axixá... Que o passageiro chamava um lugar nunca que foi ocupado pelos branco. Hoje os branco que se encontra lá estão... estão jurando de matar indio Baixinho, morador de aldeia Canabrava, filho do velho Inácio Azevedo Guajajara. Ele não quer que indio pesca mais, e nós indio estamos achando estranho, essa.. essa lagoa, que se chama Santa Luzia, é de nós indio!... Nunca nós não... nós não vamos deixar de pescar lá nessa lagoa!... E nós indio queremo é o nosso direito de volta. ${ }^{\prime \prime O}$

\section{6-2008}

Entre 1990 e 1995 cerca de 30 madeireiras instalaram-se em Amarante, para funcionar exclusivamente em função da madeira da TI Araribóia. Suas açôes impactaram, inicialmente, nas regiôes sob jurisdição dos PINs Araribóia e Canudal.

projetos fracassados., p. A4).

10 depoimento de Vitorino Soares Guajajara, na sede do ambulatório da UFMA, em Buriticupu, em 25/3/2000, gravado em vídeo. 
Em julho de 1995 uma ação do Instituto Brasileiro do Meio Ambiente e dos Recursos Naturais Renováveis (IBAMA) e da Polícia Federal realizava uma grande apreensão de toras em Amarante, interditando a maioria das madeireiras que atuavam ilegalmente na região (Zannoni, 1998).

Estas passaram, na seqüência, a atuar na região sob jurisdição do PIN Angico Torto, sempre com a conivência de lideranças indígenas e funcionários da FUNAI. Várias comunidades resistiram, no entanto, à presença das madeireiras, arrefecendo bastante o ritmo da devastação, de modo que, ainda em 1995, eram criados os PINs Zutiwa e Lagoa Comprida, "para agradar lideranças políticas que não estavam envolvidas na venda de madeira da terra indígena" (Gomes, 2002).

Em 1997, uma nova investida das madeireiras fazia-se sentir na região do PIN Angico Torto, porém em menor escala que no início da década, reativando a mobilização de suas comunidades, que novamente detiveram o processo.

Além desses impactos mais imediatos sobre o ambiente, a venda das madeiras propiciou súbito acesso dessas comunidades Guajajara, da porção sul da TI Araribóia, a dinheiro, sobretudo entre jovens homens, intensificando o consumo de bebidas alcoólicas, as viagens a Imperatriz e a freqüência a seus cabarés: estas foram as circunstâncias em que se deu a contaminação dos primeiros dois Guajajara pelo HIV.

Em setembro de 1996 era notificado o primeiro caso de Aids de pessoa indígena no Maranhão, e em março de 1998 era notificado, em Goiânia/GO, o segundo caso: com quadro clínico grave, o paciente fora encaminhado pela FUNAI/ Administração Executiva Regional de Imperatriz (AER-ITZ), em busca de melhor atendimento, ao Hospital das Clínicas da Universidade Federal de Goiás.

As informaçōes colhidas nas investigaçōes epidemiológicas, realizadas de 21 a 22 de outubro de 1996, e de 13 a 18/5/1998, numa cooperação entre Mestrado em Saúde e Ambiente (MSA) da Universidade Federal do Maranhão (UFMA), da FUNAI/AER-ITZ, do Conselho Indigenista Missionário-Regional Maranhão (CIMI-MA), do então Distrito Sanitário de Imperatriz da Fundação Nacional de Saúde (FUNASA), e do Programa de DST/Aids da Secretaria de Estado da Saúde, indicaram que ambos pacientes, além de provenientes da TI Araribóia, residiram por mais de 5 anos num bairro na área urbana do município de Amarante do Maranhão (o que tornava a comunidade daquele bairro num dos focos de atenção); seus parceiros dispersaram-se por outras comunidades indígenas da região, e pelas periferias de Grajaú e Imperatriz.

Entre 15 e 19/6/1998 realizava-se, assim, numa cooperação entre a UFMA/MSA e a FUNAI/AER-ITZ, o censo deste bairro. A análise do consolidado dos dados então coletados indica que boa parte das famílias Guajajara da região investiram os recursos da venda das madeiras na instalação de domicílios na cidade, em busca, sobretudo, de acesso a serviços de educação, e também de saúde.

A partir de meados de 2002, entretanto, algumas famílias Guajajara da região norte da TI Araribóia, movidas pela situação de total desassistência, sobretudo à saúde ${ }^{11}$, com o colapso terminal dos serviços prestados pelo Distrito Sanitário Especial Indígena da FUNASA (cf. adiante), passaram a aceitar a ação das madeireiras e carvoeiras (que se valem exatamente da prestação de pequenos - porém vitais - serviços a estas comunidades, como o transporte de água e em emergências de saúde, abertura e melhoria de picadas de acesso, para legitimar e mesmo tornar atrativos sua presença e atuação), e uma rápida devastação reiniciava na região.

Ainda em 2002, Kelé Apolinário Guajajara (de 55 anos), morador da Aldeia Abraão, foi encontrado morto dentro da mata; apesar das suspeitas recaírem sobre a ação de madeireiros, o caso nunca foi investigado.

O ritmo e a escala da retirada de madeira na região, no período, foram assustadores. Havia informações de pelo menos dois pontos de saída utilizados pelos madeireiros: um no município de Bom Jesus das Selvas, por onde saíam diariamente cerca de 30 caminhóes carregados de madeira; outro no município de Buriticupu, por onde saíam diariamente cerca de 20 caminhões.

Em fins de julho de 2007 era desencadeada, na região, a chamada "Operação Entorno": conduzida pelo IBAMA em parceria com a Polícia Rodoviária Federal, Exército e Batalhão de Policiamento Ambiental do Maranhão, que embargou 7 madeireiras por funcionarem sem licença, aplicou multas totalizando R \$ 1.354.303,00, apreendeu 4.424,895 metros cúbicos de madeira em toras e 250,519 metros cúbicos de madeira serrada.

Entre 16 e 20 agosto de 2007, em resposta à Operação Entorno, os madeireiros promoveram violenta manifestação, resultando em confronto armado, com vários feridos, bloqueio da BR 222, saques de caminhôes-baú e de estabelecimentos comerciais, e destruição de carregadeira de toras do IBAMA.

A mobilização dos madeireiros e o bloqueio da BR 222 só foram suspensos com a assinatura (por representantes do IBAMA, FUNAI e todos os órgãos de segurança, Secretarias de Estado, Prefeitura de Buriticupu, Câmara de Vereadores, Igreja Católica, Igreja Evangélica, Maçonaria, Sindicato de Madeireiros, Sindicato de Funcionários Públicos, Associação Comercial, representante do assentamento situado no

11 conforme indicam dados levantados em pesquisa de campo, realizada em dezembro/2006 pelo projeto "Indicadores de qualidade de vida de comunidades rurais, quilombolas e indígenas da Pré-Amazônia", do MSA da UFMA, junto a comunidades da porção norte da TI Araribóia. 
interior da Reserva Biológica do Gurupi, todos os órgãos de segurança do Estado, e Ministério Público) de mútuo termo de compromisso entre as partes, prevendo prazo de 90 dias para regularização das madeireiras.

No início de setembro, Guajajara da aldeia Lagoa Comprida aprenderam um caminhão madeireiro que operava na região, comunicando o fato à FUNAI e solicitando providências. Na mesma semana, os madeireiros procuraram os Guajajara e tentaram recuperar o caminhão, oferecendo mil reais e argumentando (como vêm fazendo junto a várias comunidades Guajajara, segundo depoimentos por nós colhidos) que os índios estariam sendo tolos de não permitir a exploração daquela madeira, que seria de propriedade do Governo, que cedo ou tarde a exploraria sem nada lhes pagar. Os índios se recusaram a negociar.

Em represália, por volta das seis horas da manhã de 15 de outubro, um grupo de aproximadamente quinze homens armados, três deles encapuzados, invadiram a aldeia Lagoa Comprida, mataram o Sr. Tomé Guajajara (de 60 anos) a tiros, balearam Madalena Paulino Guajajara (no tórax) e Antonio Paulino Guajajara (no braço direito). Segundo depoimentos, os invasores chegaram atirando contra os indígenas, levandoos ao campo de futebol, em que permaneceram cercados, por várias horas, pelos pistoleiros, que os ameaçavam com tiros para o alto.

$\mathrm{Na}$ retirada, os madeireiros provocaram um enorme incêndio na mata que, segundo depoimentos por nós colhidos, teria devastado os últimos resquícios de floresta ainda virgem na região, teria acarretado grande mortandade de animais, certamente com consequiências dramáticas (embora ainda desconhecidas) em relação aos grupos Awa.O documento final do "I Encontro de Caciques e Lideranças indígenas da Terra Indígena Araribóia" (aldeia Juçaral, 23-25 de novembro de 2007) faz uma detalhada retrospectiva dos fatos, chamando atenção para um aspecto fundamental da questão, freqüentemente ignorado ou dissimulado - a cumplicidade dos bancos oficiais:

“...levantamos muitas preocupações, entre elas, a questão do desmatamento provocado pelos madeireiros, das queimadas etc., e o mais grave e preocupante é o sistema de crédito dos bancos oficiais, o Banco do Nordeste e o Banco do Brasil, que incentivam a destruição das matas e dos rios quando exigem dos produtores rurais e indígenas que, ao final do período de financiamento, disponham de quantias de cabeças de gado bovino como indicadores de produtividade de suas propriedades."

Relatando os vários tipos de ameaças que vêm sofrendo dos madeireiros, o documento chama atenção para o grande aumento do risco de concretização destas ameaças, finda a Operação Entorno:
"Nós indígenas também estamos preocupados com a pós-operação, isso porque estamos recebendo notícias que os madeireiros estão se organizando para retaliar a ação da Polícia Federal, inclusive ameaçando realizar novos ataques às comunidades assim que a Polícia Federal se retirar, forçar a expulsão dos alunos indígenas que estudam em Amarante do Maranhão e Arame, bem como os moradores indígenas que ali residem." (I Encontro de Caciques e Lideranças indígenas da Terra Indígena Araribóia, 2007, p. 1).

Conforme previsto, finda a Operação Entorno, com a partida dos agentes da Polícia Federal da região, a ação das madeireiras e carvoeiras tornou a intensificar-se como dantes.

Em 20 de janeiro de 2008, a Assembléia Paroquial de Sta Luzia, reunida em Buriticupu, encaminhava carta à Diretora Regional do IBAMA, denunciando a situação:

"Nós deploramos estes ' 3 meses' de prazo que foram concedidos a fim de que as serrarias 'se legalizem', enquanto não tem mais nem 'um caniço' de mata verde na superfície de nossa paróquia” (Assembléia Paroquial de Sta Luzia, 2008).

"Nós deploramos e denunciamos este acordo porque somos testemunhas cada dia da destruição das estradas de chão que levam aos nossos assentamentos do interior, onde passam, preferivelmente de noite, numerosos caminhóes, indo para os municípios vizinhos de Bom Jardim pelo caminho de Vila Pindaré-Presa de Porco e outros caminhos do interior, carregados na volta de madeiras nobres.

Deploramos também as más condições e falta de segurança às quais são submetidos os próprios operários da madeira e denunciamos a invasão ilegal das reservas indígenas do outro lado do Rio Pindaré.

Deploramos e denunciamos a reabertura das carvoeiras, à vista de todos, sem nenhuma fiscalização nem controle das condições de exploração do que sobra de nossas matas e da vida dos próprios carvoeiros, de suas famílias e das famílias que habitam nos locais".

‥

"Nós pedimos, com muita angústia, aos nossos governantes e ao próprio IBAMA, que faça todo o possível para que cesse esta situação de "ausência de Estado" e de falta de responsabilidade ecológica, para que as nossas populaçóes e o seu meio-ambiente, no que ainda existe, sejam devidamente protegidos através da fiscalização e pela intervenção da própria força pública que não pode se satisfazer em prender aqueles que se envolveram nas confusóes que aconteceram dentro da sede do nosso município, enquanto os agressores do meio ambiente e das suas populaçóes andam soltos e até protegidos." (Assembléia Paroquial de Sta Luzia, 2008). 


\section{AWA ("GUAJÁ")}

Perambulando em grupos familiares pequenos, os chamados Awa são rápidos, silenciosos e pouco visíveis na mata. Competindo com grupos mais numerosos e poderosos, entre os quais os próprios Kaapor, muitos desses grupos Awa permanecem isolados até o momento.

A grande redução populacional dos Kaapor e dos Tembé a partir da década de 1940, em decorrência da intensificação do contato, permitiu que os Awa, no entanto, também pudessem descer, pouco a pouco, para os vales.

Alguns grupos Awa foram localizados mais a leste do rio Pindaré (Área Indígena Araribóia) e na Serra da Canastra, ao norte do que é atualmente o Estado de Tocantins, para onde teriam fugido a partir da região da TI Araribóia, tomando caminhos ao sul (Gomes, 1989).

Os Awa são um dos poucos grupos indígenas ainda estritamente nômades do planeta; sendo essencialmente caçadores e coletores, são donos de uma cultura material despojada, e vêm recusando-se sistematicamente a ceder aos presentes e demais atrativos das frentes do contato que, desde 1913, o SPI e a FUNAI tentaram estabelecer em seu território.

Seria apenas em meados da década de 1970 que alguns grupos Awa aceitariam, pela primeira vez, os presentes oferecidos no Posto Indígena Guajá, da FUNAI; o episódio atraiu o interesse de outros Awa das imediaçôes, e em 1976 a FUNAI já contabilizava cerca de seis grupos autônomos (num total de 91 pessoas) contatados na região.

À consolidação deste contato da FUNAI sucedeu-se a típica trajetória das frentes de contato com índios "isolados" ou "arredios" - epidemias de malária e de viroses de rápida disseminação, introduzidas pelos próprios indigenistas e/ ou induzidas pela súbita concentração dos grupos (antes dispersos) atraídos pela frente de contato, dizimaram, em algumas semanas, famílias e grupos inteiros: enquanto vários Awa sobreviventes tornaram a fugir, os remanescentes na área (contabilizados em número de 25 , em 1980) passaram a dedicar, pela primeira vez, boa parte de seu tempo e força de trabalho à abertura de roças (Gomes, 1989).

Nos anos 1970, foram vários os contatos e enfrentamentos entre os Awa e a frente de construção da BR 222: ataques diurnos frontais, com flechas, às máquinas e tratores em operação, e em açóes noturnas furtivas, enquanto desligados, a atar-lhes firmemente rodas e engrenagens com cipós.

Os primeiros contatos com os Awa, realizados pela FUNAI, deram-se em 1973. Das 56 pessoas então contatadas, em fevereiro de 1980, segundo relatório do próprio órgão, restavam apenas 26: as demais faleceram acometidas por gripes, pneumonias e surtos de malária. Um segundo grupo de
28 pessoas foi contatado no mesmo ano, do qual, nas semanas seguintes, faleceram seis pessoas.

Em 1974 faleceram mais quatro desses Guajá, quando de sua remoção, pela FUNAI, para a atual aldeia Awa.

Os contatos desses grupos Guajá com os Guajajara e comunidades rurais da região, inicialmente esparsos, tornaram-se cada vez mais freqüentes, ao longo das décadas de 1980 e 1990.

Em 1987, entre as aldeias Canudal e Lagoa Comprida (TI Araribóia), caçadores Guajajara depararam-se com um acampamento Guajá de oito tapiris, recentemente abandonado.

Outro grupo foi contatado pela FUNAI em 1989: de 22 pessoas contatadas logo faleceram seis, restando apenas 15 .

$\mathrm{Na}$ esteira dos projetos de desenvolvimento e grandes empreendimentos, a atividade madeireira e a carvoeira experimentaram rápida expansão na região, como vimos, a partir do final da década de 1980.

A exploração do jaborandi foi outra frente que constituiuse, ao longo dos anos 1980, numa pressão significativa dos empreendimentos de capital sobre a cobertura vegetal e as comunidades da região, e mais especificamente sobre a TI Araribóia e suas comunidades Guajajara e Awa.

Sendo estritamente caçadores e coletores, os Awa dependem inteiramente da floresta para sua sobrevivência, e nela perambulam em grupos que, em condiçôes normais, variam de 5 a 30 pessoas, no máximo (Gomes, 1989).

À medida, no entanto, em que recua a orla da mata, os Awa, encurralando-se, passam a perambular em grupos cada vez maiores, e a se expor a contatos cada vez mais freqüentes, tanto com os Guajajara, quanto com a sociedade envolvente.

Em 1987, entre as aldeias Canudal e Lagoa Comprida (TI Araribóia), realizava-se outro contato traumático de um grupo Guajá com caçadores Guajajara: estes últimos, deparando-se com um acampamento Guajá de oito tapiris, recentemente abandonado, levaram consigo vários de seus pertences (uma bola de cera, flechas e uma corda), o que teria feito os Guajá se retirarem novamente para longe, na mata.

Em 1992, um grupo de seis Awa foi contatado na fazenda Cipó Cortado, próximo ao assentamento Cikel; posteriormente, foi transferido, por funcionários da FUNAI, para o Posto Indígena (PI) Juriti (TI Caru).

Em dezembro de 1998, caçadores Guajajara encontraram vestígios de grandes acampamentos Awa (de até 60 pessoas) nas matas do município de Buriticupu - o que demonstra a mudança em sua estratégia de organização e mobilização (UFMA, 1999). 
Em 2001, segundo relato de Vitorino Guajajara, foi encontrado, na mesma região, um homem Awa morto, aparentemente por sede, já fora dos limites da TI Araribóia, numa trilha que conduz a um curso d'água.

Em função, sobretudo, das dificuldades no acesso a assistência à saúde, e no contexto da grande expansão da frente carvoeira pela Amazônia maranhense (induzida pela usinas de ferro-gusa implantadas ao longo da Estrada de Ferro Carajás), comunidades Guajajara da porção noroeste da TI Araribóia tornaram a negociar, no início dos anos 2000, com madeireiros e carvoeiros, e uma nova etapa em sua devastação tinha início.

Ainda na mesma TI Araribóia, em fins de abril de 2005 caçadores Guajajara, da aldeia Marajá, encontraram um grande acampamento Awa em suas proximidades: novamente, como em 1987, tomaram do acampamento vários de seus pertences (duas redes de palha de tucum, uma cabaça de sapucaia, cabeças de machado, muito desgastadas). Na mesma época, caçadores Guajajara da aldeia Guaruhu contataram vários grupos Awa nas proximidades da Lagoa da Sapucaia. Tornaram cada vez mais freqüentes os encontros, relatados por caçadores Guajajara, de restos mortais de Awa em localidades que sugerem que estariam em busca de água; os Guajajara supõem que vários Awa tenham morrido de sede mesmo, nestes últimos anos. Suas lagoas, que antes eram perenes, começam a secar por conseqüências do desmatamento, e a busca por água torna-se cada vez mais difícil.

Uma equipe da FUNAI, preparando-se para uma nova operação, até então sigilosa, de atração e remoção destes grupos Guajá da TI Araribóia para as aldeias Awa, Tiracambu e Juriti, na TI Caru, viu frustrados seus planos, em junho de 2006, pelo súbito falecimento do Guajá To'o, da aldeia Juriti, que lhe serviria de intérprete. $\mathrm{O}$ episódio forçou a FUNAI a assumir publicamente, pela primeira vez, seus planos de remoção: segundo informações pouco precisas do órgão, To'o falecera por infarto agudo do miocárdio, à noite, enquanto dormia num hotel em Santa Inês.

A perspectiva de iminente extinção desses grupos Guajá, indicada por estas notícias e relatos, ganhou repercussão a ponto da Survival International desencadear campanha internacional em sua defesa, em novembro de 2006.

Estimamos que, atualmente, a população total dos Awa alcance cerca de 400 pessoas, distribuídas entre um território contínuo na Amazônia maranhense - Terra Indígena (TI) Alto Turiaçu (2 grupos, num total de cerca de 70 pessoas), TI Awa/ Reserva Biológica do Gurupi (5 grupos, num total de cerca de 50 pessoas) e TI Caru (9 grupos, sendo dois "arredios", num total de cerca de 150 pessoas) e no prolongamento desse ecossistema, em áreas mais ao leste e ao sul: TI Araribóia (cerca de 100 pessoas) e na Serra da Canastra, município de Goiatins/ TO (cerca de 10 pessoas).

\section{DISCUSSÃO}

\section{"AUSÊNCIA DO ESTADO"(?): VULNERABILIDADE SOCIAL DE COMUNIDADES RURAIS E GUAJAJARA, GENOCÍDIO AWA IMINENTE}

Hoje encontram-se, entre as comunidades Guajajara da porção sul da TI Araribóia, acesso a número bem maior de domicílios urbanos (vários com telefone) do que entre as comunidades da porção norte da TI Araribóia, assim como de pessoas alfabetizadas, matriculadas em escolas e mesmo com ensino médio completo.

Já as comunidades Guajajara da porção norte da TI Araribóia, resistindo por mais tempo às ofertas das madeireiras, vivem numa região de cobertura vegetal mais preservada, tendo melhores condições para manter suas fontes e padrões alimentares tradicionais, também apresentando, de modo geral, melhor perfil epidemiológico (nenhum caso de Aids até o momento).

Por outro lado, essas comunidades têm tido acesso a políticas, programas e serviços de educação e saúde, de modo geral, em número e qualidade bem inferiores que as da porção sul, na região de Amarante do Maranhão. Na região de Arame há um número bem menor de Guajajara alfabetizados e que tenham freqüentado a rede escolar formal - o que se reflete, inclusive, em sua maior vulnerabilidade social, em sua menor capacidade de acompanhar, apreender e de interferir na condução das políticas e serviços públicos a eles voltados.

Quanto aos Awa, a experiência de trabalho de várias instituições e entidades com comunidades indígenas, e na região, indicam que essas ações de contato, atração e, sobretudo, remoção de grupos inteiros, são de grande risco, e sempre resultam em grande número de mortes e danos à sua saúde e qualidade de vida - além de serem ilegais, uma vez que realizadas sem prévia consulta e aprovação pelo Congresso Nacional, conforme determina o $\$ 5 .^{\circ}$ do artigo 231 da Constituição de 1988.

Diante da gravidade e urgência da situação, e com base nestes argumentos, em 31 de outubro de 2006 a Sociedade Maranhense de Direitos Humanos, o Conselho Indigenista Missionário-Regional Maranhão, a Comissão Pastoral da Terra, a Caritas Brasileira, o Mestrado em Saúde e Ambiente e o Departamento de Sociologia e Antropologia da UFMA, e o Gabinete da Deputada Estadual Helena Helluy, encaminharam representação à Procuradoria da República no Maranhão, solicitando levantamento de informações mais precisas acerca das causas da morte de To'o Guajá, investigação de mais este fracassado (e ilegal) plano de remoção de grupo Guajá, e providências para garantir a efetiva não intrusão das TI Araribóia e demais TIs habitadas por Guajá no estado. 
O fracasso da Operação Entorno reitera o já disposto, muito anteriormente, em nossos relatórios de pesquisa ${ }^{12}$ : não há perspectivas de sucesso para açôes repressivas isoladas (da parte da FUNAI, do IBAMA e/ou da Polícia Federal) contra a ação das madeireiras e das carvoeiras, na região: é indispensável que as açôes repressivas sejam precedidas e estejam articuladas a um amplo e massivo investimento de políticas públicas, voltado tanto às comunidades da TI Araribóia, quanto às de trabalhadores rurais dos arredores.

$\mathrm{Na}$ situação de total desassistência por parte dos serviços e instituiçōes públicas da região, os madeireiros e carvoeiros valem-se exatamente da prestação de pequenos - porém vitais - serviços a estas comunidades indígenas e rurais (transporte de água e em emergências de saúde, abertura e melhoria de picadas, entre outros), para legitimar e mesmo tornar atrativos sua presença.

Pesquisa realizada, em dezembro de 2006, pelo Núcleo de Extensão e Pesquisa com populaçóes e comunidades Rurais, Negras Quilombolas e Indígenas (NuRuNI) do Mestrado em Saúde Ambiente da UFMA ${ }^{13}$, entre comunidades indígenas da região, indicam que o que as tem levado a permitir a ação das madeireiras e carvoeiras é sua decisão de captar recursos, em caráter emergencial, para acesso a serviços de saúde (à diferença das comunidades da região de Amarante na década de 1990, em busca sobretudo de serviços de educação), decorrente da ausência, para estas comunidades, de quaisquer serviços do chamado Distrito Sanitário Especial Indígena do Maranhão da FUNASA (que, a rigor, nunca chegou a funcionar segundo modelo preconizado pelo próprio órgão), no contexto de seu precoce sucateamento.

É necessário que proceda ampla articulação entre as instituiçōes responsáveis pelas políticas públicas (federais, estaduais e municipais) na região e as instituiçôes, entidades e movimentos sociais ali atuantes, com vistas a definir medidas emergenciais, e de curto, médio e longo prazos, para resgatar da miséria essas comunidades rurais e Guajajara, deter o processo de devastação da TI Araribóia e a iminente extinção de seus grupos Awa.

\section{O MARANHÃO E O "CICLO DO CANGAÇO"}

No Maranhão contemporâneo, sobretudo em sua chamada região tocantina, o aguçamento dos conflitos agrários da década de 1980 (envolvendo o Projeto de Colonização Agrícola de Buriticupu e as ações do Grupo Executivo das Terras do Araguaia-Tocantins - GETAT) desencadearia, ao longo dos anos 1990, uma verdadeira profissionalização da violência (Feitosa, 1994, p. 269), que se tornou famosa por seu organizado mercado de pistoleiros, em que chegaram

12 projeto "Indicadores de qualidade de vida de comunidades rurais, quilombolas e indígenas, na Pré-Amazônia"

13 Idem. a vigorar tabelas com faixas ascendentes de preços para a execução, respectivamente, de lavradores, sindicalistas, padres, fazendeiros e políticos (Isto É, 1993).

Foi basicamente do universo cultural da pecuária sertaneja $^{14}$ (sobre a cultura "sertaneja" - cf. Ribeiro, 1997), dentre os vaqueiros das grandes fazendas financiadas pela SUDAM, que emergiram estes profissionais - fenômeno, de resto, já comentado por vários autores, em contextos históricos e sociais distintos (Durham, 1973).

$\mathrm{Na}$ Amazônia maranhense e na região tocantina, onde os pecuaristas são largamente hegemônicos no controle dos aparelhos de estado locais e regionais, a profissionalização da violência, não se deu na forma de um cangaço propriamente dito (como ocorrido em Pernambuco, Ceará, Paraíba, Rio Grande do Norte, Alagoas, Sergipe e Bahia, dos anos 1920, tempos de Lampião e Corisco) - em que os cangaceiros, iniciando carreira como assaltantes organizados, chegaram a representar uma ameaça aos governos de estado - mas dáse por uma organização mais discreta de jagunços, menos evidenciada que nesses outros estados, porque mais dispersa e colocada justamente a serviço dos poderosos, desenvolvida e organizada em conivência com os "coronéis" modernos, donos do poder local/municipal, coniventes com os projetos de desenvolvimento regional de um "coronel" maior (ou de um "major", como no caso do GETAT...), estadual - conivente, por sua vez, com o projeto nacional hegemônico.

No que se refere ao Maranhão, essa "jagunçagem" desenvolveu-se com o apoio, justamente, do poder local, estadual e federal.

Por seu projeto de contestação aos interesses da oligarquia açucareira do baixo Pindaré, nos anos 1920 e 1930, a aliança entre trabalhadores rurais e os Guajajara, na região, protagonizada por Antônio Bastos, representa um importante contraponto, no contexto do Maranhão, às configurações sociais do cangaço propriamente dito, nos demais estados nordestinos.

\section{LITERATURA CITADA}

Araújo, H.F.A. 2000. Memória, mediação e campesinato - estudo das representaçôes de uma liderança sobre as formas de solidariedade assumidas por camponeses na chamada Pré-Amazônia Maranhense. Dissertação de mestrado, Mestrado em Políticas Públicas, Universidade Federal do Maranhão, São Luís, Maranhão. 181 pp.

Assembléia Paroquial de Sta Luzia. 2008. Carta à Diretora Regional do IBAMA. Assembléia Paroquial de Sta Luzia, Buriticupu, $\mathrm{MA}, \mathrm{BR}$, 4pp.

14 "sertão s.m. 'região agreste, distante das povoacões ou das terras cultivadas'" (Cunha, 1982, p. 718) "Lugar sertão se divulga: é onde os pastos carecem de fecho onde um pode torar dez, quinze léguas, sem topar com casa de morador; e onde 0 criminoso vive o seu cristo-jesus, arredado do arrocho da autoridade." (Rosa, 1976, p. 9). 
Conceição, M. 1980 (entrevista e edição de Galano, AM). Essa terra é nossa: depoimento sobre a vida e a luta de camponeses no Estado do Maranhão. Vozes, Petrópolis, RJ, BR. 212pp.

Conselho Indigenista Missionário - Regional do Maranhão, 1988. Povos Indígenas no Maranhão. Conselho Indigenista Missionário - Regional do Maranhão, São Luís, MA, BR. 104 pp.

Cunha, A.G. 1982. Dicionário etimológico nova fronteira da lingua portuguesa. Nova Fronteira, Rio de Janeiro, RJ, BR. 988pp.

Dória, C.A. 1982. O Cangaço. Brasiliense, São Paulo, SP, BR. 99pp.

Droulers, M.; Maury, P. 1981. Colonização da Amazônia Maranhense. In: Ciência e Cultura: 1033-1050.

Durham, E. 1973. A caminho da cidade: a vida rural e a migração para São Paulo. Perspectiva, São Paulo, SP, BR. 249pp.

Eid, A.S.F. 1979. Pelo espaço do cangaceiro, Jurubeba. Símbolo, São Paulo, SP, BR. 176 pp.

Feitosa, R.M.M. 1994. O processo sócio-econômico do Maranhão. Dissertação de Mestrado, Universidade Federal do Pará. Belém, Pará. 411pp.

Figueiredo, R.M.B. 2000. Fronteira e identidade: um estudo sobre os deslocamentos de "maranhenses" para o sudeste do Pará como estratégia de manutenção da condição camponesa. Dissertação de Mestrado, Universidade Federal do Maranhão. São Luís, Maranhão. 111pp.

Gomes, M.P. 1989. O povo Guajá e as condiçôes reais para sua sobrevivência. Mimeo, Rio de Janeiro, RJ, BR. 47pp.

Gomes, M.P. 2002. O indio na história: o povo Tenetehara em busca da liberdade. Vozes, Petrópolis, RJ, BR. 631pp.

Gonçalves, M.F.C. 2000. A Reinvenção do Maranhão dinástico. Editora da Universidade Federal do Maranhão, São Luís, MA, BR. 195pp.

I Encontro de Caciques e Lideranças indígenas da Terra Indígena Araribóia, 2007. Documento final. Aldeia Juçaral, Terra Indígena Araribóia, Amarante do Maranhão, MA, BR. 4 pp.

Instituto Socioambiental, 2001. Povos Indígenas no Brasil 1996/2000. Instituto Socioambiental, São Paulo, SP, BR. 834pp.
Isto É, 1993. A vida por um palmo de terra. São Paulo, 19 de maio de $1993, \mathrm{n}^{\circ} 1233$, p. 59.

Luna, R. C. M. R. A terra era liberta: um estudo da luta dos posseiros pela terra no vale do Pindaré - Ma. Universidade Federal do Maranhão/Secretaria Educação Ma, São Luís, MA, BR. 146 pp.

Marques, C.A. 1970. Dicionário histórico e geográfico da Província do Maranhão. Fon-Fon/Seleta, Rio de Janeiro, RJ, BR. 689pp.

Ribeiro, D. 1997. O povo Brasileiro - a formação e o sentido do Brasil. Companhia das Letras, São Paulo, SP, BR. 476pp.

Rosa, J.G. 1976. Grande sertão: veredas. José Olympio, Rio de Janeiro, RJ, BR. 460pp.

Sader, M.R.C.T. 1986. Espaço e luta no Bico do Papagaio. Tese de Doutorado, Universidade de São Paulo. São Paulo, São Paulo. 242 pp.

Sales, N.P. 1993. Pressão e resistência dos indios Tembé-Tenetehara do alto rio Guamá e a relação com o território. Dissertação de Mestrado, União das Escolas Superiores do Pará/Diretoria de Pesquisa. Belém, Pará. 93pp.

Universidade Federal do Maranhão, Fundação Nacional de Saúde, 1994. Projeto Buriticupu. Universidade Federal do Maranhão, São Luís, MA, BR. 39pp.

Varga, I.V.D. 2002. Pelas fronteiras e trincheiras do indigenismo e do sanitarismo: a atenção às DST em comunidades indígenas, no contexto das politicas e práticas indigenistas e de saúde, na Pré-Amazônia. Tese de Doutorado, Universidade de São Paulo, Faculdade de Saúde Pública, São Paulo, São Paulo. 449pp.

Wagley, C.; Galvão, E. 1961. Os indios Tenetehara. Uma cultura em transição. Ministério da Educação e Cultura, Rio de Janeiro, RJ, BR. 237pp.

Zannoni, C. 1999. Conflito e coesão: o dinamismo Tenetehara. Conselho Indigenista Missionário. Brasília, DF, BR. 246pp.

Recebido em 17/05/2007

Aceito em 14/12/2007 